\title{
Pengaruh Literasi Ekonomi Terhadap Perilaku Konsumtif Mahasiswa Jurusan Pendidikan Ekonomi Universitas Siliwangi
}

\author{
Oleh \\ Ai Nur Solihat ${ }^{1}$, Syamsudin Arnasik \\ ainur.nury@gmail.com
}

\begin{abstract}
ABSTRAK
Penelitian ini bertujuan untuk mengetahui gambaran mengenai pengaruh literasi ekonomi terhadap perilaku konsumtif mahasiswa Jurusan Pendidikan Ekonomi Universitas Siliwangi. Metode yang digunakan dalam penelitian ini adalah metode deskriftif. Populasi dalam penelitian ini adalah mahasiswa Jurusan Pendidikan Ekonomi Universitas Siliwangi. Teknik sampling yang digunakan dalam penelitian ini adalah simple random sampling dengan jumlah responden sebanyak 251 orang. Teknik pengumpulan data berupa tes, angket dan dokumentasi. Teknik analisis data yang digunakan dalam penelitian ini adalah regresi linier sederhana, dimana yang menjadi varialel indipenden $(X)$ adalah literasi ekonomi dan variabel dependen $(Y)$ adalah perilaku konsumtif. Hasil penelitian menunjukkan bahwa literasi ekonomi memiliki pengaruh yang singnifikan terhadap perilaku konsumtif mahasiswa Jurusan Pendidikan Ekonomi Universitas Siliwangi. Artinya jika terjadi peningkatan literasi ekonomi maka semakin rasional perilaku konsumtif mahasiswa.
\end{abstract}

Kata Kunci : Literasi ekonomi, Prilaku konsumtif

\section{The Effect of Economic Literacy on Consumer Behavior of Economics Department Students of Siliwangi University}

\author{
Ai Nur Solihat ${ }^{1}$, Syamsudin Arnasik² \\ ainur.nury@gmail.com
}

\begin{abstract}
This study aims to determine the description of the influence of economic literacy on student consumptive behavior Department of Economic Education Siliwangi University. The method used in this research is a descriptive method. The population in this study are students of the Department of Economic Education Siliwangi University. The sampling technique used in this study is simple random sampling with 251 respondents. Data collection techniques in the form of tests, questionnaires, and documentation. Data analysis technique used in this research is a simple linear regression, where the independent variable $(X)$ is economic literacy and the dependent variable $(Y)$ is consumptive behavior. The results show that economic literacy has a significant influence on student consumptive behavior. This means that if there is an increase in economic literacy, the more rational student consumptive behavior.
\end{abstract}

Keyword : economic literacy, consumptive behaviour 


\section{Pendahuluan}

Manusia dan ekonomi merupakan dua hal yang tidak dapat dipisahkan. Ekonomi adalah ilmu yang mempelajari tentang penggunaan sumber daya yang terbatas untuk memenuhi kebutuhan manusia yang tidak terbatas. Semua kebutuhan ini digunakan untuk mempertahankan kelangsungan hidupnya, namun tidak semua kebutuhan manusia dapat dipenuhi. Hal ini terjadi karena sifat manusia yang tidak pernah puas akan segala sesuatu yang dimilikinya, dan sumber daya yang ada tidak cukup untuk memenuhi semua kebutuhan manusia tersebut. Keterbatasan sumber daya inilah yang kemudian kita kenal sebagai kelangkaan.

Pengelolaan sumber daya yang dimiliki masyarakat merupakan hal yang penting karena menyangkut kelangkaan. Kelangkaan (scarcity) berarti masyarakat memiliki sumber daya yang terbatas atau langka sehingga mereka tidak dapat menghasilkan barang dan jasa sebanyak yang diinginkan. Keinginan untuk memenuhi kebutuhan hidup merupakan naluri manusia. Dalam memenuhi kebutuhannya manusia dihadapkan pada masalah ekonomi yang berlaku sebagai akibat adanya ketidakseimbangan antara kebutuhan manusia yang tidak terbatas dengan alat pemuas kebutuhan yang jumlahnya terbatas. Permasalahan ekonomi tersebut merupakan penghalang dalam usaha manusia dalam mencapai tujuan. Setiap manusia pasti ingin hidup makmur, sejahtera, serta mampu menghadapi masalah jangka pendek seperti konsumsi sehari-hari serta pemenuhan kebutuhan lainnya. Terbatasnya sumber daya yang tersedia dibandingkan dengan kebutuhan, menyebabkan manusia dihadapkan pada pilihan-pilihan yang bersifat individu dan kolektif.

Sebagai makhluk ekonomi dan juga sebagai makhluk sosial, manusia dituntut untuk dapat mengatasi masalah-masalah ekonomi dan masalah sosial. Keterbatasan sumber daya yang dimiliki seseorang mengakibatkan orang tersebut tidak mampu untuk memenuhi apa saja yang diiginkan. Manusia sebagai makhluk ekonomi, dituntut memiliki pengetahuan yang logis dalam memilih berbagai alternatif alat pemuas kebutuhan untuk mendapatkan kepuasan yang optimal. Upaya manusia dalam memenuhi kebutuhan konsumsinya untuk mencapai kepuasan yang optimal itu tampak dari perilaku sebagai konsumen.

Era globalisasi mengakibatkan terjadinya pergeseran pola konsumsi sebagian besar masyarakat di Indonesia. Pengaruh globalisasi sangat terlihat di kota-kota besar, termasuk di kota Tasikmalaya. Dampak globalisasi semakin terasa setelah muncul pusat-pusat perbelanjaan dan berbagai macam barang dan jasa yang tersedia. Hal tersebut menunjukkan mudahnya memperoleh barang -barang yang beraneka ragam dan kemudahan dalam fasilitas yang lainnya.

Pergeseran perilaku konsumsi tersebut disebabkan karena adanya pengadopsian nilai-nilai baru yang bersifat positif maupun negatif. Perilaku tersebut berimbas pada sebagian besar mahasiswa dan remaja tanpa memandang pendapatan orang tua. Peran orang tua dalam pembelian barang-barang kebutuhan anaknya mulai tergeser seiring dengan perkembangan teknologi dan informasi yang cepat. Untuk masa sekarang ini, dalam membeli suatu barang, remaja cenderung tidak meminta pertimbangan dari orang tua tetapi mereka lebih percaya kepada teman pergaulannya. Keadaan seperti ini yang telah menjadi kebiasaan para mahasiswa sekalipun mereka belum memperoleh penghasilan sendiri. Kecenderungan mengarah kepada konsumsi yang kurang efektif, yaitu perilaku konsumsi yang tidak lagi mempertimbangkan keadaan ekonomi orang tuanya, tetapi mereka lebih cenderung mengikuti mode dan trend, serta pengaruh dari iklan televisi dan teman pergaulan.

Sekarang ini tidak sedikit ditemui remaja yang bergaya hidup memburu kepuasan dan kesenangan pribadi tanpa memperhatikan kondisi ekonomi orang tuanya yang mencari uang untuk biaya hidup. Dalam benak mereka hanya tertanam kesenangan dan kepuasan, serta gaya hidup glamour. Sementara kondisi ekonomi orang tua tidak memungkinkan untuk memberikan fasilitas pemenuhan kebutuhan yang berlebihan. Bahkan ada yang memaksakan kehendak dengan menggunakan uang kuliah untuk membeli sesuatu karena gengsi dan untuk mengejar kepuasan, padahal sebenarnya barang tersebut belum dibutuhkan.

Terkait dengan perilaku konsumtif mahasiswa, pendidikan memiliki peranan penting dalam meningkatkan sumber daya manusia yang berkualitas. Pendidikan merupakan suatu 
proses pembelajaran dalam mengambil keputusan. Selain memiliki perilaku yang lebih baik, manusia yang memiliki pengetahuan cenderung memiliki kecakapan hidup yang lebih baik.

Mahasiswa yang merupakan bagian terpenting dari proses pendidikan, proses pendidikan yang didapatkan mahasiswa di kampus merupakan proses pendidikan tertinggi. Dalam artian bahwa mahasiswa sudah mencapai tahapan pembelajaran teringgi yang merupakan tahap perubahan tingkah laku yang lebih baik sesuai dengan hasil yang ingin dicapai dari proses pendidikan. Dengan kata lain, orang dianggap belajar jika menunjukkan perubahan-perubahan tingkah laku dalam hidupnya.

Mahasiswa Jurusan Pendidikan Ekonomi yang memiliki pengetahuan tentang ilmu ekonomi dan dalam proses pembelajaran sudah memasuki tahap atas maka dapat dikatakan mereka memiliki perubahan perilaku yang lebih baik dan matang. Dalam memenuhi kebutuhannya khususnya dalam perilaku konsumsinya mahasiswa Jurusan Pendidikan Ekonomi akan berprilaku sesuai dengan pengetahuan yang dipelajarinya selama perkuliahan. Artinya, mahasiswa jurusan Pendidikan ekonomi ini memiliki tingkat pemahaman literasi ekonomi yang baik. Oleh karena itu, literasi ekonomi menjadi bagian yang sangat penting dalam pengambilan keputusan untuk memenuhi kebutuhan hidup. Sebagaimana diungkapkan oleh Sina (2012:135), literasi ekonomi merupakan alat yang berguna untuk merubah perilaku dari tidak cerdas menjadi cerdas. Seperti bagaimana memanfaatkan pendapatan untuk menabung dan berinvestasi, proteksi, dan memenuhi kebutuhan hidup. Pentingnya literasi ekonomi akan meminimalisir perilaku konsumtif mahasiswa dalam berkonsumsi. Begitupun menurut Neti Budiwati (2014: 19) literasi ekonomi penting dalam kehidupan sehari-hari. Pernyataan tersebut sejalan dengan pendapat Gary H. Stern Presiden Federal Reserve Bank of Minneapolis dalam Nuraeni (2015:9) bahwa "Melek ekonomi sangat penting karena merupakan ukuran apakah orang memahami kekuatan yang secara signifikan mempengaruhi kualitas hidup mereka".

\section{Landasan Teori}

\subsection{Konsep Perilaku Konsumsi}

\subsubsection{Konsumsi, Konsumtif, dan Konsumerisme}

Manusia adalah makhluk sosial yang cenderung hidup dalam kelompok atau komunitas. Dalam kehidupan sehari-hari, kebutuhan manusia dapat dipenuhi karena keberadaan dan kontribusi orang lain yang terhubung dalam sebuah jalinan interaksi yang kompleks dan sistemis. Tingkat ketergantungan antar individu ini berbeda dari satu masyarakat dengan masyarakat lain.

Ekonomi merupakan ilmu tentang perilaku dan tindakan manusia untuk memenuhi kebutuhan hidupnya yang bervariasi, dan berkembang dengan sumber daya yang ada melalui pilihan-pilihan kegiatan produksi, konsumsi, dan atau distribusi. Konsumsi pada dasarnya adalah mata rantai terakhir dalam rangkaian aktivitas ekonomi tempat diubahnya modal, dalam bentuk uang menjadi komoditas-komoditas melalui proses produksi. Adapun yang dimaksud masyarakat konsumen adalah sebuah masyarakat yang cenderung diorganisasikan di seputar konsumsi ketimbang produksi barang dan jasa.

Kegiatan konsumsi merupakan suatu kegiatan yang bertujuan untuk mengurangi atau menghabiskan nilai guna suatu barang atau jasa dalam rangka memenuhi kebutuhan. Ini dilakukan manusia untuk memenuhi kebutuhan hidupnya secara langsung. Setiap individu dan masyarakat secara umum mempunyai kecenderungan tertentu dalam melakukan konsumsi. Kecenderungan mengkonsumsi disebut dengan pola konsumsi.

Pola konsumsi yang menggambarkan pilihan seseorang bagaimana ia menggunakan waktu dan uang dapat dicerminkan oleh gaya hidup. Sebagaimana diungkapkan oleh Solomon dalam Sumarwan (2015: 45) bahwa "lifestyle refers to a pattern of consumption reflecting a person's choices of how he or she spend time oan money."

Gaya hidup lebih menggambarkan perilaku seseorang yaitu bagaimana ia hidup, menggunakan uangnya, dan memanfaatkan waktu yang dimilikinya. Gaya hidup sering kali digambarkan dengan kegiatan, minat, dan opini dari seseorang. Gaya hidup seseorang biasanya tidak permanen dan lebih cepat berubah. Seseorang mungkin cepat mengganti 
model dan merek pakaian karena menyesuaikan dengan kebutuhan hidupnya. . Dalam hal ini muncul istilah yang menggambarkan kondisi dari tindakan konsumsi, yaitu konsumtif dan konsumerisme.

Konsumtif merupakan kegiatan menghabiskan nilai guna suatu barang atau jasa bukan berdasarkan kebutuhan, melaikan faktor gengsi. Dalam The Theory of The Leisure Class, Veblen menjelaskan hal-hal yang berhubungan dengan dorongan dan pola perilaku konsumsi masyarakat. Veblen dalam Deliarnov (2015:147) menyebutkan bahwa "Conspicious consumption of valuable goods is a means of reputability to gentlemen of leisure." Ketika penyebaran informasi semakin masif, dan pasar sering menawarkan berbagai macam produk yang menggiurkan, menggugah selera dan cita rasa konsumen, maka yang kemudian terjadi adalah pemanfaatan waktu senggang menjadi suatu yang mereduksi sebagai aktivitas pleasure, bersenang-senang, hedonis, dan bahkan identik dengan berbelanja. Konsumen memanfaatkan nilai uang lebih besar dari nilai produksinya untuk barang dan jasa yang bukan menjadi kebutuhan pokok, dalam hal ini Veblen melihatnya sebagai tindakan yang bermotif bersenang-senang (leisure), sehingga mendorong seseorang untuk berlomba-lomba membeli barang-barang mewah yang digunakan untuk pamer, tidak peduli apakah barang tersebut berguna atau tidak dalam kehidupan sehari-hari. (Deliarnov, 2015: 147).

Perilaku konsumsi yang mencolok (consicious consumption) di masyarakat terjadi karena pada dasarnya manusia bukanlah konsumen yang otonom, melainkan apa yang mereka lakukan dan konsumsi untuk dinilai lebih oleh orang-orang disekitarnya. Manusia dalam kehidupan sehari-hari cenderung senang bergaya untuk memamerkan diri. Kelompok the leisure class ini, untuk memperlihatka dan membedakan mereka dengan kelas sosial lain, biasanya akan mengembangkan gaya hidup dan perilaku konsumsi tersendiri yang cenderung berlebihan dan boros sebagai simbol status tinggi mereka. The leisure class ini merupakan kelas pemboros yang memboroskan uang, waktu, tenaga kerja, dan menikmati gengsi serta status tinggi. Kondisi demikianlah yang dinamakan dengan konsumerisme yang dinamakan masyarakat konsumsi (consumer society) yaitu masyarakat yang lebih mementingkan memenuhi keinginan ketimbang memenuhi kebutuhan (Suyanto, 2013:257).

Menurut Maslow dalam Sumarwan (2015:26) bahwa kebutuhan manusia itu berjenjang yang dikenal dengan Teori Maslow atau Hierarki Kebutuhan Manusia. Maslow mengemukakan lima kebutuhan manusia berdasarkan tingkat kepentingannya mulai dari yang paling rendah, yaitu kebutuhan iologis, sampai paling tinggi yaitu kebutuhan psikogenik. Manusia berusaha memenuhi kebutuhan tingkat rendahnya terlebih dahulu sebelum memenuhi kebutuhan yang lebih tinggi. Konsumen yang telah bisa memenuhi kebutuhan dasarnya, maka kebutuhan lainya yang lebih tinggi biasanya muncul, dan begitu seterusnya. Gambar Hierarki Kebutuhan Maslow dapat dilihat pada Gambar 2.1.

Derajat tertinggi dari kebutuhan adalah keinginan seorang individu untuk menjadikan dirinya sebagai orang yang terbaik sesuai dengan potensi dan kemampuan yang dimilikinya. Kebutuhan aktualisasi diri menggambarkan keinginan seeorang untuk mengetahui, memahami, dan membentuk suatu sistem nilai, sehingga ia bisa mempengaruhi orang lain. Kecenderungan untuk pamer seperti yang diungkapkan Veblen merupakan kebutuhan konsumen dalam aktualisasi diri.

Dalam proses aktualisasi diri ini, konsumen berlomba-lomba mencari barang-barang mewah dengan harga yang sangat mahal. Tidak peduli barang tersebut berguna dalam kehidupan sehari-hari atau tidak. Manfaat dari pengkonsumsian barang-barang mahal tersebut memang tidak diperoleh dari barang itu sendiri, tetapi melalui dampaknya terhadap dan melalui orang lain. Makin mahal barang yang dibeli, konsumen akan merasa semakin hebat. Kepuasan dari barang yang ditunjukan untuk pamer tidak diterima dari pengkonsumsian barang-barang itu sendiri, melainkan melalui dampaknya terhadap orang lain. Konsumen membeli suatu barang yang melebihi proporsi yang wajar, jelas tidak rasional (Deliarnov, 2015: 147-148) Perilaku konsumen yang berlebih-lebihan dalam mewujudkan aktualisasi diri tersebut akan mengarah kepada konsumerisme. 


\subsubsection{Teori Perilaku Konsumen}

Menurut Engel et al, perilaku konsumen adalah tindakan yang langsung terlibat dalam pemerolehan, pengkonsumsian, dan penghabisan produk/jasa, termasuk proses yang mendahuluinya dan menyusul tindakan ini. Menurut Mowen dan Minor, perilaku konsumen adalah studi unit-unit dan proses pembuatan keputusan yang terlibat dalam penerimaan, penggunaan dan pembelian, dan penentu barang, jasa dan ide. Schiffman dan kanuk mendefinisikan perilaku konsumen sebagai perilaku yang diperlihatkan konsumen untuk mencari, membeli, menggunakan, mengevaluasi dan menghabiskan produk dan jasa yang mereka harapkan akan memuaskan kebutuhan mereka. (Etta Mamang Sangadji, 2013:7-8)

Pada kenytaannya, dalam hidup manusia sering dihadapkan pada berbagai pilihan guna memenuhi kebutuhannya. Pilihan-pilihan ini terpaksa dilakukan karena kebutuhan masnusia tidak terbatas, sedangkan alat pemuas kebutuhan tersebut sangat terbatas. Banyak faktor dan alasan yang mendorong manusia untuk melalukan suatu pembelian. Pemahaman tentang perilaku mereka sangat penting karena dapat dijadikan modal penting bagi perusahaan untuk mencapai tujuannya.

Menurut Griffin dalam Etta Mamang Sangiadji (2013 : 8) menyebutkan bahwa perilaku konsumen adalah semua kegiatan, tindakan serta proses psikologi yang mendorong tindakan tersebut pada saat sebelum membeli, ketika membeli, menggunakan, menghabiskan produk dan jasa setelah melakukan hal-hal di atas atau kegiatan mengevaluasi. Sementara menurut Ariely dan Zauberman menyebutkan bawa perilaku konsumen merupakan tindakantindakan yang dilakukan oleh individu, kelompok, organisasi yang berhubungan dengan proses pengambilan keputusan untuk mendapatkan, menggunakan barang-barang, atau jasa ekonomis yang dapat dipengaruhi lingkungan.

Dari pengertian yang dikemukakan oleh para ahli, dapat disimpulkan bahwa perilaku konsumen adalah tindakan yang dilakukan konsumen guna mencapai dan memenuhi kebutuhannya baik untuk menggunakan, mengkonsumsi, maupun menghabiskan barang dan jasa, termasuk keputusan yang mendahului dan yang menyusul. Dengan demikian, perilaku konsumen dapat disimpulkan bahwa :

1. Disiplin ilmu yang mempelajari perilaku individu, kelompok, atau organisasi dan prosesproses yang digunakan konsumen untuk menyeleksi, menggunakan produk, pelayanan, pengalaman (ide) untuk memuaskan kebutuhan dan keinginan konsumen, dan dampak dari proses-proses tersebut pada konsumen dan masyarakat.

2. Tindakan yang dilakukan oleh konsumen guna mencapai dan memenuhi kebutuhannya baik dalam penggunaan, pengonsumsian, maupun penghabisan barang dan jasa, termasuk proses keputusan yang mendahului dan yang menyusul.

3. Tindakan atau perilaku yang dilakukan konsumen yang dimulai dengan merasakan adanya kebutuhan dan keinginan, kemudian berusaha mendapatkan produk yang diinginkan, mengkonsumsi produk, tersebut, dan berakhir dengan tindakan-tindakan pasca pembelian, yaitu perasaan puas dan tidak puas.

(Etta Mamang Sangiadji, 2013:9).

Menurut McKechnie dalam Etta Mamang Sangiadji (2013:9) menyebutkan bahwa

"The fiel of Consumer Behaviour: studies how individuals, groups, and organizations select, buy, use, and dispose of goods, services, ideas, or experiences to satisfy their needs and desires". Dari pengertian tersebut dapat dijabarkan tahapan-tahapan perilaku konsumen, meliputi:

1. Tahap untuk merasakanadanya kebutuhan dan keinginan

2. Usaha untuk mendapatkan produk, mencari informasi tentang produk, harga, dan saluran distribusi

3. Pengonsumsian, penggunaan, dan pengevaluasian produk setelah digunakan

4. Tindakan pasca pembelian yang berupa perasaan puas atau tidak puas.

Disiplin perilaku konsumen adalah salah satu cabang dari ilmu sosial. Perilaku konsumen memanfaatkan metode riset yang berasal dari disiplin psikologi, sosiologi, ekonomi, dan antropologi dalam meneliti perilaku manusia sebagai konsumen. Salah satu 
dimensi penting dari perilaku konsumen adalah motivasi atau alasan konsumen menggunakan produk tertentu.

Menurut Suwarman (2015:5), Riset perilaku konsumen terdiri atas tiga perspektif dimana ketiga perspektif tersebut sangat mempengaruhi cara berpikir dan mengidentifikasi faktor-faktor yang mempengaruhi perilaku konsumen. Ketiga perspektif tersebut yaitu :

1. Perspektif pengambilan keputusan. Konsumen melakukan serangkaian kativitas dalam membuat keputusan pembelian. Perspektif ini mengasumsikan bahwa konsumen memiliki masalah dan melakukan proses pengambila keputusan yang rasional untuk memecahkan masalah tersebut.

2. Perspektif Eksperiensial (pengalaman). Perspektif ini mengemukakan bahwa konsumen sering kali mengambil keputusan membeli suatu produk tidak selalu berdasarkan keputusan rasional untuk memecahkan masalah yang mereka hadapi. Konsumen sering kali membeli sesuatu produk karena alasan kegembiraan, fantasi, ataupun emosi yang diingikan.

3. Perspektif Pengaruh Behavioral. Perspektif ini menyatakan bahwa seorang konsumen membeli suatu produk sering kali bukan karena alasan rasionalatau emosional yang berasal dari dalam dirinya. Perilaku konsumen dalam perspektif ini menyatakan bahwa perilaku konsumen sangat dipengaruhi oleh faktor luar seperti program pemasaran yang dilakukan oleh produsen, faktor budaya, faktor lingkungan fisik, faktor ekonomi dan undang-undang, serta pengaruh lingkungan yang kuat membuat konsumen melakukan pembelian.

Dalam ilmu ekonomi, perilaku konsumen dijelaskan melalui teori perilaku konsumen. Teori perilaku konsumen dapat menjelaskan bagaimana cara seorang konsumen memilih suatu produk yang diyakininya akan memberikan kepuasan maksimum dengan dibatasi oleh pendapatan dan harga barang. Dalam teori perilaku konsumen ini, semua pelaku ekonomi termasuk juga konsumen diasumsikan selalu memaksimumkan kepuasan dengan kendala yang dihadapinya. Permasalahan konsumen yaitu dihadapkan pada berbagai pilihan dalam mengalokasikan anggarannya untuk membeli sejumlah barang. Dengan sumber daya yang terbatas, setelah proses berpikir, konsumen menentukan pilihan optimalnya. Teori perilaku konsumen ini dapat dibedakan dalam dua pendekatan yaitu pendekatan nilai guna (utility) kardinal dan pendekatan nilai guna ordinal.

\section{A. Pendekatan Nilai Guna (Utility) Kardinal}

Di dalam ekonomi kepuasan yang diperoleh seseorang dari mengkonsumsi barangbarang dinamaan nilai guna atau utility. Jika kepuasan semakin tinggi maka semakin tinggilah nilai gunanya atau utilitinya.Keputusan untuk mengkonsumsi suatu barang berdasarkan perbandingan anatara manfaat yang diperoleh dengan biaya yang harus dikeluarkan. Nilai kegunaan yang diperoleh dari konsumsi disebut utilitas total (TU). Tambahan kegunaan dari penambahan satu unit barang yang dikonsumsi disebut utilitas marginal (MU). Menurut Sadono Sukirno (2015:154) menyebutkan bahwa :

Nilai guna total ( Total Utility) adalah dapat diartikan sebagai jumlah seluruh kepuasan yang diperoleh dari mengkonsumsikan sejumlah barang tertentu. Sedangkan nilai guna marginal (Marginal Utility) berarti pertambahan (atau pengurangan) kepuasan sebagai akibat dan pertambahan (atau pengurangan) penggunaan suatu unit barang.

Di dalam pendekatan nilai guna (utility) berlaku hukum nilai guna marginal yang semakin menurun yang menyatakan bahwa tambahan nilai guna yang akan diperoleh seseorang dari mengkonsumsikan suatu barang akan menjadi semakin sedikit apabila orang tersebut terus menerus menambah konsumsinya ke atas barang tersebut. Pada akhirnya tambahan nilai guna akan menjadi negatif yaitu apabila menambah satu unit barang yang dikonsumsi, maka nilai kegunaan totalnya akan semakin berkurang. Artinya penambahan yang terus menerus dalam mengkonsumsi suatu barang tidak secara terus menerus menambah kepuasan bagi konsumen yang menikmatinya. Seperti yang diungkapkan oleh Rahardja dan Manurung (2010:78) bahwa : 
Pada awalnya penambahan konsumsi suatu barang akan memberi tambahan utilitas yang besar, tetapi makin lama penambahan itu bukan saja semakin menurun, bahkan menjadi negatif. Good sudah berubah menjadi Bad. Gejala itu disebut sebagai Hukum Penambahan Manfaat yang semakin menurun (The Low od Diminsihing Marginal Utility). Dalam analisis perilaku konsume, gejala ini dapat dilihat dari makin menurunnya nilai utilitas marginal. Karena dasar analisisnya adalah perubahan utilitas marginal.

\section{B. Pendekatan Ordinal}

Menurut pendekatan ordinal, kegunaan tidak dapat diukur melainkan cukup untuk sekedar diketahui saja dan konsumen membuat preferensi (urutan) daya guna dari barang yang dikonsumsinya. Agar kepuasan tersebut tercapai maka konsumen memiliki preferensi dari berbagai kebutuhannya. Preferensi konsumen dapat dijelaskan dengan menggunakan kurva indeferens (indifference curve), yaitu kurva yang menunjukkan berbagai kombinasi konsumsi dua macam barang yang memberikan tingkat kepuasan yang sama bagi seorang konsumen. Sama hal nya seperti yang diungkapkan oleh Sadono Sukirno (2015:170) bahwa kurva indiferens dapat didefinisikan sebagai suatu kurva yang menggambarkan ganungan barang-barang yang akan memberikan kepuasan yang sama besarnya.

Kurva indeferen menjelaskan bahwa utiliti meningkat bila konsumen berpindah ke kurva indiferens yang lebih tinggi, misalnya dari $U_{1}$ ke $U_{2}$ atau ke $U_{3}$. Ini menggambarkan mengenai preferensi seorang konsumen. Memilih utiliti yang lebih tinggi bukan berarti konsumen mencapai kepuasan maksimal, karena ada constraint yang dihadapi konsumen yaitu pendapatan. Oleh karena itu selain berdasarkan kurva indiferens, perilaku konsumen juga dapat ditunjukkan oleh budget line, sehingga dapat pula dilihat efek perubahan pendapatan dan harga.

Garis anggaran (budget line) adalah kurva yang menunjukkan kombinasi konsumsi dua macam barang yang membutuhkan biaya (anggaran) yang sama besar. Kemiringan (slope) kurva budget line adalah negatif, yang merupakan harga dari setiap barang.

Melalui kurva indeferens dan budget line diketahui kombinasi barang yang akan dikonsumsi oleh konsumen, dalam Gambar 2.3 tidak ditunjukkan oleh utiliti tertinggi $\left(\mathrm{U}_{2}\right.$ atau $U_{3}$ ) karena jauh di atas garis anggaran $(P-Q)$, sehingga utilitas maksimal konsumen dicapai pada $U_{1}$. Pada $U_{1}$ diketahui kombinasi barang yang memberi utilitas tertinggi, yaitu pada kombinasi yang ditunjukkan oleh titik $\mathrm{B}$ dan titik $\mathrm{C}$, yang berada pada budget line.( Neti Budiwati, 2014 : 29-30)

Konsep preferensi berkaitan dengan kemampuan konsumen menyusun prioritas pilihan agar dapat mengambil keputusan. Menurut Rahardja dan Manurung (2010:79) menyatakan bahwa :

Konsep preferensi berkaitan dengan kemampuan konsumen menyususn prioritas pilihan agar dapat mengambil keputusan. Ada dua sikap yang berkaitan dengan preferensi konsumen, yaitu sikap lebih suka (prefer) dan atau sama-sama disukai (indifference). Misalnya ada dua barang $X$ dan $Y$, maka konsumen mengatakan $X$ lebih disukai daripada $Y(X>Y)$ atau $X$ sama-sama disukai seperti $Y(X=Y)$. Tanpa sikap ini perilaku konsumen sulit dianalisis. Syarat lain agar perilaku konsumen dapat dianalisis, konsumen hrus memiliki konsistensi preferensi. Bila barang $X$ lebih disukai dari $Y(X>Y)$ dan barang $Y$ lebih disukai dari $Z(Y>Z)$, maka barang $X$ lebih disukai dari $Z(X>Z)$. Konsep ini disebut transitivitas (transcitivity). 


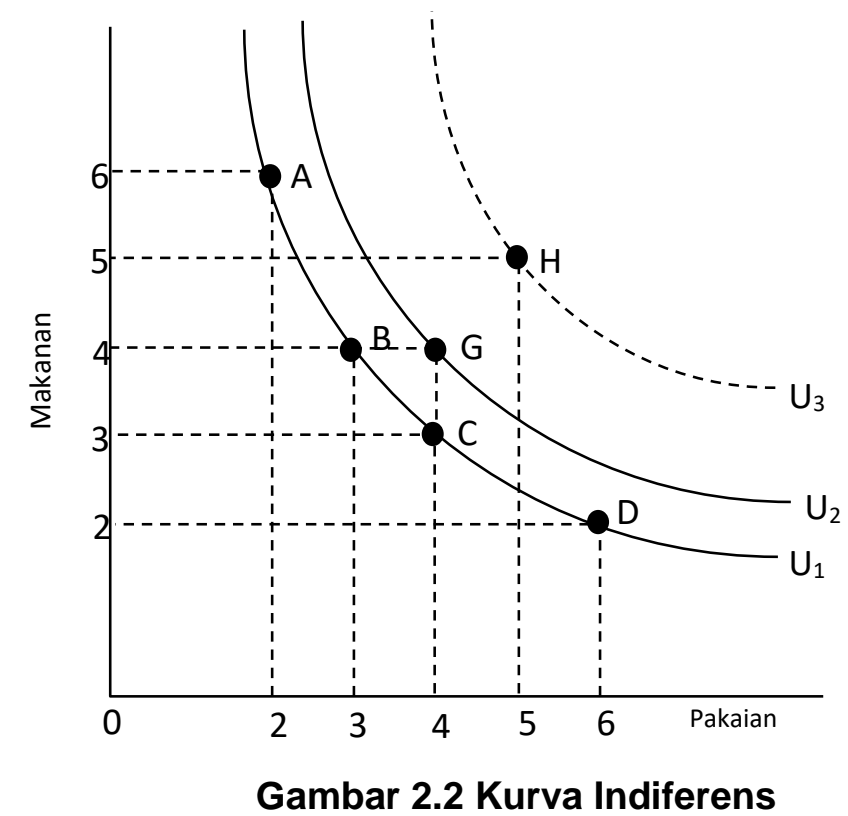

Dalam teori pilihn rasional, individu dapat dilihat sebagai sangat rasional, mampu melakukan yang terbaik untuk memuaskan keinginannya, Menurut Molm dalam Sindung Haryanto (2011:108) menyebutkan bahwa teori pilihan rasional menganut pandangan atomis, yaitu memfokuskan pada preferensi dan pilihan individu sebagai basis untuk menjelaskan perilaku sosial, termasuk konstruksi dan utilisasi institusi. Sedangkan Willimsons dalam Sindung Haryanto (2011:108) berpendapat bahwa perilaku ekonomi secara fundamental terdiri dari transaksi-transaksi, yaitu pertukaran nilai antar individu. Untuk mempertahankan kepentingan masing-masing pihak, individu merancang kontrak yang dimasudkan untuk mengatur perilaku.

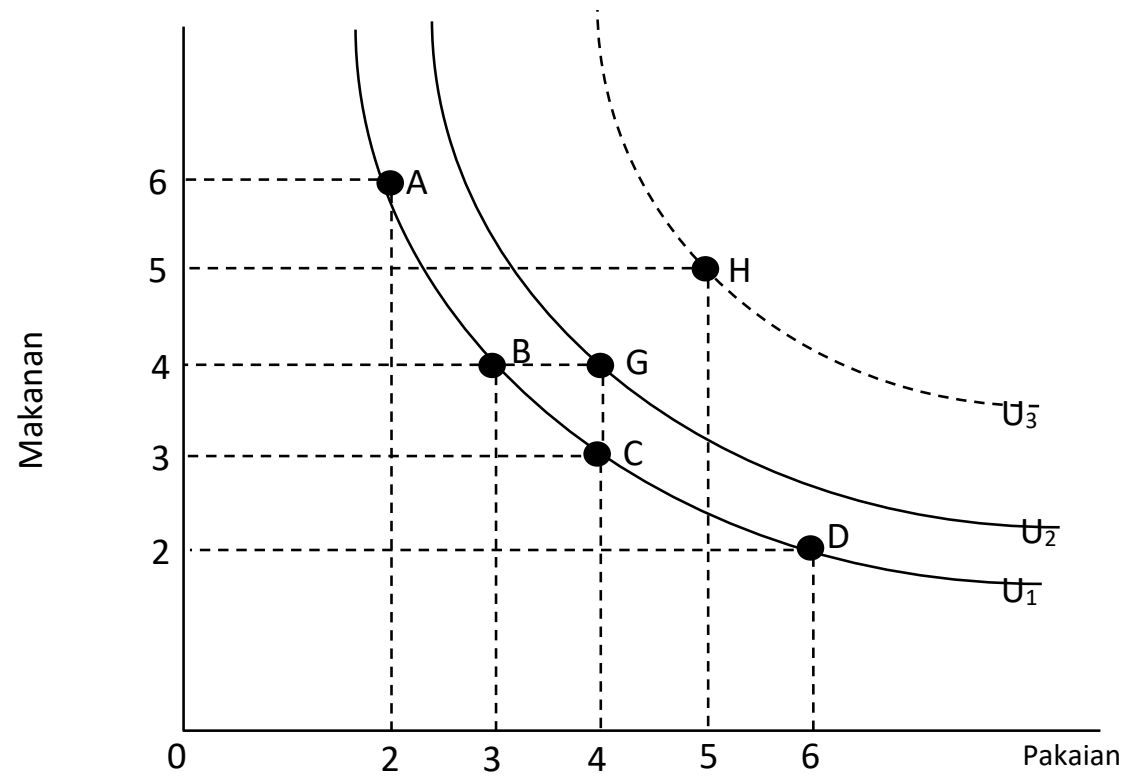

Gambar 2.3 Kurva utilitas maksimal

Dengan demikian agar konsumen dapat mencapai utiliti maksimal, maka perlu tindakan rasional dalam memutuskan barang atau jasa yang akan dibeli, sehingga konsumen harus memperhatikan berapa anggaran yang tersedia. Walaupun konsumen berusaha menghabiskan pendapatan untuk mencapai kepuasan maksimal, namun bukan berarti 
seluruh pendapatan dihabiskan untuk konsumsi sehingga konsumen dituntut untuk menyusun daftar preferensi kebutuhannya dan daftar anggaran pendapatan dan belanja.

\subsection{Konsep Literasi Ekonomi}

\subsubsection{Pengertian Literasi}

Istilah literasi menunjuk pada huruf, sehingga terkadang literasi diterjemahkan sebagai keaksaraan. Ini sesuai dengan makna hurufiah bahwa literasi adalah kemampuan membaca dan menulis. Berdasarkan istilah itu, orang yang tidak bisa membaca disebut orang yang literat atau biasa diterjemahkan buta aksara. Karena literasi pada dasarnya berkenaan dengan keaksaraan, orang yang memiliki kemampuan membaca dan menulis disebut orang melek akasara atau melek huruf. Hal tersebut dinyatakan dalam Dictionary of Problem Words and Expressions (Iriantara, 2009:3) bahwa :

Literat dan literasi itu berkenaan dengan huruf. Oleh karena itu dinyatakan, orang yang memiliki kemampuan literasi pada dasarnya adalah orang yang bisa membaca dan menulis. Namun dalam kamus ini pun selanjutnya dijelskan pula bahwa "semua orang hendaknya bisa membaca dan menulis, namun kemampuan ini memerlukan kerja keras dan harus banyak belajar sehingga bisa sungguh-sungguh menjadi orang yang disebut literat.

Dalam bahasa Inggris, literasi berasal dari kata literacy yang berarti melek huruf, atau membaca dan menulis atau memiliki pengetahuan atau kompetensi. Menurut Dorothy B. Durband (2012:20), literacy is defined as being literate or "able to read and write"or "having knowledge or competence. Sejalan dengan artikel yang ditulis oleh Peter Sina dalam Kompasiana edisi 01 Mei 2012 definisi Literasi menurut Collins Dictionary and Thesaurus bahwa literasi berarti kemampuan membaca, menulis, pendidikan, pembelajaran dan pengetah.an. Sedangkan menurut UNESCO dalam Iriantara (2009 : 4) menjelaskan bahwa literasi adalah kemampuan seorang individu untuk membaca fdan menulis yang ditandai dengan kemampuan memahami pernyataan singkat yang ada hubungannya dengan kehidupannya,

Dari beberapa pengertian di atas dapat disimpulkan bahwa literasi adalah serangkaian langkah yang terpadu untuk membuka cakrawala berpikir sehingga mampu bersikap dengan tepat. Didasari definisi tersebut tampak bahwa literasi memainkan peranan penting dalam kehidupan sehari-hari. Nalarnya adalah bermodalkan literasi maka orang akan mampu melakukan penyesuaian yang dibutuhkan dengan menggunakan informasi yang relevan.

Perkembangan ilmu pengetahuan dan teknologi, melahirkan tantangan yang menuntut manusia memiliki kemampuan literasi lain, di luar melek huruf. Sejalan dengan perkembangan literasi ini, ada tiga perkara penting yang perlu kita perhatikan yaitu :

1. Kita harus bisa memahami proses belajar seperti apa yang bisa membuat orang literate.

2. Kita perlu menganalisis peninkatan jumlah neo-literasi

3. Kita perlu mengkaji seperti apa keterampilan yang harus diberikan kepada masyarakat saat ini seperti halnya kita dulu menerima pembelajaran membaca dan menulis. (Varis dalam Iriantara, 2009:5)

\subsubsection{Pengertian Ekonomi}

Kata ekonomi berasal dari bahasa Yunani yakni Oikonomia. Artinya manajemen rumah tangga. Asal katanya adalah Oikos yang berarti rumah tangga dan Nomos yang berarti peraturan, aturan, atau hukum. Oikonomia adalah aturan masyarakat sebagai hukum kodrat yang menetapkan rumah tangga yang baik. IImu ekonomi membahas segala jenis pokok bahasan. Namun pada intinya ditujukan untuk memahami bagaimana masyarakat mengalokasikan sumber-sumber dayanya yang langka. Menurut Samuelson (1992:4), ilmu ekonomi merupakan suatu studi tentang perilaku masyarakat dalam menggunakan sumber daya yang langka dalam rangka memproduksiberbagai komoditi, untuk kemudian menyalurkannya kepada berbagai individu dan kelompok yang ada dalam suatu masyarakat. 
IImu ekonomi sering dikaitkan dengan uang. Jika belajar ilmu ekonomi harus bisa mengatur dan memiiki uang. Padahal seorang sarjana ekonomi tidak harus kaya dan belum tentu dapat hidup hemat. Uang memang dipelajari dalam ilmu ekonomi, tetapi bukan satusatunya permasalahan dalam ilmu ekonomi. Yang menjadi permasalahan dalam ilmu ekonomi adalah kelangkaan (scarcity). Kelangkaan sumber daya relatif terhadap pemenuhan kebutuhan, sementara jumlah kebutuhan manusia tidak terbatas. Dengan demikian, untuk mendapatkan kepuasan dengan alat pemuas kebutuhan yang terbatas maka manusia harus melakukan pemilihan kebutuhan dengan cara mengalokasikan sumber daya yang ada secara efisien. Ilmu ekonomi membantu manusia untuk mencapai kemakmuran yang maksimal dari sumber-sumber atau alat-alat yang tersedia.

Menurut Iskandar dalam Nuraeni (2015: 18) ilmu ekonomi terbagi dalam dua bagian besar yang kelak akan menurunkan ilmu-ilmu ekonomi teori dan terapan, yaitu ilmu ekonomi mikro dan ilmu ekonomi makro. Ilmu ekonomi mikro khususnya mempelajari perilaku individu dan rumah tangga produksi atau perusahaan dalam membuat keputusan untuk mengalokasikan sumber daya yang terbatas. Aspek analisisnya antara lain analisa biaya/manfaat, teori permintaan dan penawaran, elastisitas, model-model pasar, industri, teori harga dan teori produksi. Sedangkan ilmu ekonomi makro mempelajari perilaku masyarakat (negara/bangsa) dalam memenuhi kebutuhannya (masalah agregat). Aspek analisisnya antara lain pendapatan nasional, neraca pembayaran, kesempatan kerja, inflasi, dan investasi.

\subsubsection{Pengertian Literasi Ekonomi}

Literasi ekonomi atau melek ekonomi adalah pemahaman dan pengetahuan dasar teori ekonomi, konsep dan aplikasi. Perkembngan ilmu pengetahuan dan teknologi dalam pasar ekonomi global, masyarakat sebagai konsumen membutuhkan pengetahuan dasar mengenai ilmu ekonomi dalam mengalokasikan pendapatannya untuk pengambilan keputusan dalam memanfaatkan sumber daya yang terbatas guna memenuhi kebutuhan yang tidak terbatas. Oleh karena itu, literasi ekonomi atau melek ekonomi sangat diperlukan.

Masyarakat yang memiliki pengetahuan tentang ekonomi akan lebih memahami kebijakan pemerintah daripada masyarakat yang tidak memiliki pemahaman mengenai literasi ekonomi. Yang paling penting, kita sebagai konsumen harus memiliki pengetahuan dan pemahaman mengenai literasi ekonomi dalam menggunakan sumber daya yang terbatas untuk memenuhi kebutuhan yang tidak terbatas. Dengan adanya literasi ekonomi konsumen dapat menentukan berbagai alternatif pilihan dalam memanfaatkan sumber daya yang terbatas dalam memenuhi kebutuhan hidupnya. Hal tersebut diungkapkan oleh Farah Yasmin et al (2014) bahwa :

Economic literacy is the understanding and knowledge of basic economic theories, concepts and their application. In today's global and market-based economy simple literary is not enough. The current era of technological advancement requires economically literate persons who are capable of producing big revenues by taking the right decisions at the right point of time. It is not true that economic literacy is simply for a business purpose. It has equal significance for democracy. People who have knowledge about economics can understand the government's policies better than those who don't possess this understanding (Lipset, 1959). Most importantly, we all are consumers thus we must be economically literate to save our limited resources. Therefore, economic literacy is supposed by many to be an essential part of the country's future development programmed. The need of economics literacy is vital, particularly when all citizens make choices as income earners, voters and consumers. This means that economics learning cannot be limited to a special group of students, such as labour or for those who will be future leaders in government; the college bound economics students and business (Hashim and Kayode, 2013). Economics literacy is very important in all nations to prepare students for the changing world financial system. Underdeveloped countries are facing many difficulties to improve economic 
performance and living standards. Students will need more economic understanding to participate actively in the changing global economy (Walstad and Allgood, 1999).

Literasi ekonomi sangat penting dipelajari semua negara untuk mempersiapkan masyarakat dalam menghadapi sistem keuangan yang sealu berubah. Masyarakat akan membutuhkan pemahaman yang lebih ekonomis untuk berpartisipasi secara aktif dalam ekonomi global yang cenderug berubah.

Menurut Pandey \& Bhattacharya, melek ekonomi adalah kemampuan untuk menggunakan konsep ekonomi untuk membuat keputusan tentang penghasilan, tabungan, pengeluaran dan mengalokasikan uang. Hal ini diperjelas oleh pendapat dari Organization for Economic Literacy (OEL) yang menegaskan bahwa melek ekonomi tidak hanya meliputi pemahaman konsep dasar ekonomi dan fakta ekonomi, tetapi juga tentang kemampuan berpikir kritis yang mendukung cara berpikir ekonomi yang benar. Dengan kata lain, melek ekonomi melibatkan pengetahuan dan penerapan teori-teori ekonomi yang mendasar dalam mengambil keputusan tentang sumber daya yang terbatas. Sedangkan menurut Jappelli (2009) pada prinsipnya literasi ekonomi merupakan alat untuk mencapai tujuan, hanya saja pada kenyataannya tidak semua orang memiliki literasi ekonomi yang tinggi sehingga mengkerucutkan peluang mencapai kesejahteraan. Salah satu indikatornya adalah menjadi orang yang cerdas dalam mengelola sumber daya ekonominya guna mencapai kesejahteraan. (Nuraeni, 2015:18).

Berdasarkan beberapa pendapat di atas, dapat disimpulkan bahwa literasi ekonomi merupakan kemampuan untuk menggunakan konsep dasar ekonomi dan cara berpikir kritis dalam pembuatan keputusan ekonomi. Literasi ekonomi dapat membuat seseorang menjadi cerdas dalam mengelola sumber daya ekonomi untuk mencapai kesejahteraan dengan cara mengaplikasikan konsep ekonomi tersebut.

\section{Metodologi}

Metode penelitian pada dasarnya merupakan cara ilmiah untuk mendapatkan data dengan tujuan tertentu. Metode penelitian dapat memberikan gambaran kepada para peneliti mengenai langkah-langkah yang perlu dilakukan dalam penelitian. Dalam melakukan penelitian diperlukan pemilihan metode yang tepat, sehingga dapat memberikan kemudahan untuk memecahkan masalah yang diteliti. Dalam penelitian ini penulis menggunakan metode analisis deskriptif.

Dalam pelaksanaan penelitian tidak terlepas dari objek penelitian, karena merupakan alat yang dipergunakan untuk memecahkan masalah atau penunjang keberhasilan penelitian. Yang menjadi populasi dalam penelitian ini adalah seluruh mahasiswa Jurusan Pendidikan Ekonomi Faukltas Keguruan dan IImu Pendidikan Universitas Siliwangi Tasikmalaya sebanyak 671 orang.

Adapun teknik sampel yang dipergunakan yaitu teknik simple random sampling (sample acak sederhana) karena tanpa memperhatikan strata yang ada dalam populasi itu. Besarnya sampel penelitian ini ditetapkan dengan menggunakan rumus ukuran sampel dari Slovin dalam Neti Budiwaty (2014:89) dengan rumus sebagai berikut:

Keterangan :

$$
n=\frac{N}{1+N e^{2}}
$$

$\mathrm{n}=$ jumlah sampel

$\mathrm{N}=$ jumlah populasi $=671$ orang

$\mathrm{e}^{2}=$ level of error yang ditetapkan $=0,05$

$n=\frac{671}{1+671(0,05)^{2}}=250,60$

Dibulatkan menjadi 251 orang 
Berdasarkan perhitungan di atas, maka besarnya ukuran sampel dalam penelitian ini adalah 251 orang.

\section{Hasil Penelitian dan Pembahasan \\ 4.1 Deskripsi Objek Penelitian}

Responden dalam penelitian ini adalah mahasiswa Jurusan Pendidikan Ekonomi yang terpilih untuk dijadikan sampel yaitu berjumlah 251 orang. Karakteristik responden ini dapat diketahui dari hasil kuesioner yang disebar pada mahasiswa. Adapun karakteristik responden yang dapat dikumpulkan dalam penelitian ini meliputi jenis kelamin, tahun masuk ke jurusan pendidikan ekonomi, dan usia.

Tabel 5.1 Deskripsi Responden Berdasarkan Jenis Kelamin

\begin{tabular}{ccc}
\hline Jenis Kelamin & Frekuensi & Persentase \\
\hline $\mathbf{L}$ & 82 & 32.7 \\
$\mathbf{P}$ & 169 & 67.3 \\
Jumlah & 251 & 100.0 \\
\hline
\end{tabular}

Tabel 5.1 diketahui bahwa responden dalam penelitian ini mayoritas berjenis kelamin perempuan yaitu sebanyak 169 orang atau 67,3 persen, sedangkan mahasiswa laki-laki sebanyak 82 orang atau 32,7 persen. Artinya Jurusan Pendidikan Ekonomi FKIP Universitas siliwangi banyak diminati oleh perempuan.

Tabel 5.2 Deskripsi Responden Berdasarkan Usia

\begin{tabular}{ccc}
\hline Usia & Frekuensi & Persentase \\
\hline $17-19$ & 140 & 55,8 \\
$20-22$ & 99 & 39,4 \\
$>22$ & 12 & 4,8 \\
Jumlah & 251 & 100 \\
\hline
\end{tabular}

Tabel 5.2 menunjukkan bahwa responden dalam penelitian ini mayoritas berusia antara 17 - 19 tahun yaitu sebanyak 140 orang atau sebesar 55,8 persen. Responden yang berusia 20 - 22 tahun berjumlah 99 orang atau sebesar 39,4 persen, dan responden yang berusia di atas 22 tahun berjumlah 12 orang atau sebesar 4,8 persen. Tabel 5.2 menjelaskan bahwa usia mahasiswa Jurusan Pendidikan Ekonomi berada pada usia remaja.

\subsection{Analisis Data}

Dalam penelitian ini terdapat satu variable bebas $(X)$ yaitu literasi ekonomi dan satu variable terikat ( $Y$ ) Perilaku Konsumtif. Untuk menguji ada tidaknya pengaruh variable bebas terhadap variable terikat, dilakukan pengujian regresi linear sederhana dengan menggunakan bantuan program SPSS 21 (Output terlampir). Berdasarkan hasil pengujian tersebut dapat dianalisis beberapa hal yaitu koefisien korelasi $(R)$ variable $X$ terhadap $Y$ diperoleh sebesar 0,313 artinya literasi ekonomi memiliki korelasi (hubungan) sebesar 31,3 persen terhadap perilaku konsumtif mahasiswa. Sedangkan koefisien determinasi $\left(R^{2}\right)$ sebesar 0,098 menunjukkan bahwa perilaku konsumtif mahasiswa Jurusan Pendidikan Ekonomi dipengaruhi oleh literasi ekonomi sebesar 9,8 persen, sedangkan sisanya sebesar 90,2 persen dipengaruhi oleh faktor-faktor lain di luar literasi ekonomi.

Berdasarkan hasil pengujian data, dapat dirumuskan pula bentuk persamamaan regresi linear sederhana sebagai berikut :

$$
\hat{Y}=44,373+1,082 X
$$

Persamaan tersebut dapat diterjemahkan bahwa tanpa adanya pengaruh litersi ekonomi, perilaku konsumtif mahasiswa sebesar 44,373 satuan. Literasi ekonomi memiliki koefisien regresi sebesar 1,082 artinya jika terjadi penambahan literasi ekonomi sebesar 1 satuan maka perilaku konsumtif mahasiswa akan bertambah sebesar 1,082 satuan. 
Untuk menguji hipotesis langkah awal yang dilakukan adalah melihat besarnya $F_{\text {hitung. }}$ Besarnya $F_{\text {hitung }}$ dalam penelitian ini adalah 27,073 sedangkan Ftabel pada tingkat signifikansi 95\% dengan derajat kebebasan 1 dan numerator 251 diperoleh $F_{\text {tabel }}$ sebesar 3,85. Untuk mengambil keputusan menerima atau menolak hipotesis adalah dengan membandingkan $F_{\text {hitung }}$ dengan $F_{\text {tabel. }}$ Kriteria yang dilakukan adalah $F_{\text {hitung }}>F_{\text {tabel, }}$ maka $\mathrm{H} 1$ diterima dan $\mathrm{H}_{0}$ ditolak, dan sebaliknya. Dengan membandingkan besaran $F_{\text {tabel }}$ dan $F_{\text {hitung }}$ pada penelitian ini maka $\mathrm{H} 1$ diterima dan $\mathrm{H} 0$ ditolak, artinya secara simultan faktor literasi ekonomi berpengaruh signifikan pada perilaku konsumtif mahasiswa jurusan Pendidikan Ekonomi FKIP UNSIL.

Selanjutnya untuk menguji hipotesis secara parsial dilakukan melalui uji t. Thitung diperoleh sebesar 5,203. Pada tingkat signifikansi 95\% dengan derajat kebebasan 1 diperoleh $t_{\text {tabel }}$ sebesar 1,65251. Besarnya thitung untuk faktor iterasi ekonomi lebih besar dari $t_{\text {tabel. }}$. Dengan demikian $\mathrm{H}_{0}$ ditolak dan $\mathrm{H}_{1}$ diterima. Dengan ditolaknya $\mathrm{H}_{0}$ berarti faktor litarasi ekonomi berpengaruh signifikan terhadap perilaku konsumtifmahasiswa FKIP UNSIL.

\subsection{Pembahasan}

Hasil penelitian mengungkapkan bahwa literasi ekonomi berpengaruh terhadap perilaku konsumtif mahasiswa sebesar $9,8 \%$. Hasil ini menunjukkan bahwa perilaku konsumtif dipengaruhi oleh seberapa tinggi tingkat literasi ekonomi, semakin tinggi tingkat literasi ekonomi maka akan semakin rasional perilaku konsumtif mahasiswa, dan sebaiknya. Dimensi lieterasi ekonomi dalam penelitian ini meliputi pengetahuan, sikap, dan keterampilan ekonomi yang sifatnya praktis dan berhubungan dengan kehidupan sehari-hari.

Perilaku konsumen ditentukan oleh tingkat pengetahuan masyarakat tentang ekonomi, sehingga literasi ekonomi menjadi hal penting. Literasi dalam perekonomian suatu negara menjadi penting, karena dengan literasi ekonomi berarti menunjukkan masyarakat suatu negara merupakan konsumen atau produsen yang cerdas, sehingga akan mendorong terhadap pertumbuhan ekonomi.

Masyarakat yang cerdas akan mampu memilih produk yang dapat mendorong perekonomian negaranya, bukan memperkaya negara lain sebagaimana yang menjadi tujuan dari globalisasi. Terkait dengan perilaku konsumsi remaja atau mahasiswa, pendidikan memegang peranan penting dalam meningkatkan sumber daya manusia berkualitas. Pendidikan merupakan suatu proses yang mengakibatkan terjadinya perubahan-perubahan dalam perilaku.Dapat dikatakan bahwa orang dianggap belajar jika menunjukkan perubahanperubahan tingkah laku dalam hidupnya.

Dengan pengetahuan yang dimiliki, manusia dapat bertindak atau berperilaku sesuai dengan pengetahuan yang didapatnya dari proses pembelajaran termasuk dalam mengambil keputusan. Keputusan ekonomi yang cerdas terlihat dari kemampuan mencari sumber daya yang dimiliki untuk menciptakan benefit. Hal ini diperjelas oleh Sina Dalam Dias Kanserina (2015) bahwa literasi ekonomi berguna untuk merubah perilaku dari tidak cerdas menjadi cerdas. Pentingnya literasi ekonomi akan meminimalisir perilaku konsumtif mahasiswa dalam berkonsumsi. Seperti yang diungkapkan oleh Neti Budiwati (2014) bahwa rendahnya literasi ekonomi akan berdampak pada sikap konsumtif pada konsumen.

Literasi ekonomi atau melek ekonomi sangat diperlukan dalam pengambilan keputusan dalam memenuhi kebutuhan hidup. Masyarakat sebagai konsumen membutuhkan pengetahuan dasar mengenai ilmu ekonomi dalam mengalokasikan pendapatannya. Masyarakat yang memiliki pengetahuan tentang ekonomi akan lebih memahami kebijakan pemerintah daripada masyarakat yang tidak memiliki pemahaman mengenai literasi ekonomi. Yang paling penting, kita sebagai konsumen harus memiliki pengetahuan dan pemahaman mengenai literasi ekonomi dalam menggunakan sumber daya yang terbatas untuk memenuhi kebutuhan yang tidak terbatas. Dengan adanya literasi ekonomi konsumen dapat menentukan berbagai alternatif pilihan dalam memanfaatkan sumber daya yang terbatas dalam memenuhi kebutuhan hidupnya. 


\section{Kesimpulan}

Berdasarkan data yang diperoleh dari hasil analisis yang dilakukan, maka dapat disimpulkan bahwa literasi ekonomi memiliki pengaruh yang singnifikan terhadap perilaku konsumtif mahasiswa Jurusan Pendidikan Ekonomi Fakultas Keguruan dan Ilmu Pendidikan Universitas Siliwangi. Artinya jika terjadi peningkatan literasi ekoonomi pada mahasiswa maka semakin rasional perilaku konsumtif mahasiswa.

\section{Daftar Pustaka}

Buku :

Arikunto, Suharsimi. (2010). Prosedur Penelitian Suatu Pendekatan Praktik. Jakarta : PT. Rineka Cipta.

Deliarnov. (2015). Perkembangan Pemikiran Ekonomi. Jakarta : Pt. Raja Grafindo Persada. Gujarati, Damodar. (1998). Ekonometrika Dasar. Jakarta : Erlangga.

Haryanto, Sindung. (2011). Sosiologi Ekonomi. Jakarta : Ar-Ruzz Media.

Iriantara, Yosal. (2009). Literasi Media Apa, Mengapa, Bagaimana. Bandung : Simbiosa Rekatama Media.

Mankiw, N. Gregory. (2014). Pengantar Ekonomi Mikro Edisi Asia. Jakarta : Salemba Empat. Rahardja, Pratama dan Mandala Manurung. (2010). Teori Ekonomi Mikro Suatu Pengantar. Jakarta : Lembaga Penerbit Fakultas Ekonomi Universitas Indonesia.

Samuelson, Paul A. (1992). Mikroekonomi Edisi Keempatbelas. Jakarta : Erlangga.

Sangaji, Etta Mamang. (2013). Perilaku Konsumen Pendekatan Praktis. Jakarta : CV. Andi Offset.

Sugiyono. (2012). Metode Penelitian Kuantitatif dan R\&D. Bandung : Alfabeta.

Sukirno, Sadono. (2015) Mikroekonomi Teori Pengantar. Jakarta : PT. Radja Grafindo Persada.

Sumarwan, Ujang. (2014). Perilaku Konsumen Teori Dan Penerapannya Dalam Pemasaran. Bogor : Ghalia Indonesia.

\section{Artikel, Jurnal, Skripsi Tesis dan Disertasi}

Budiwati, Neti. (2014). Disertasi : Analisis Literasi Ekonomi Dan Perilaku Konsumen. (Survey pada Guru SMA di Kota Bandung). Bandung : Universitas Pendidikan Indonesia.

Disney, Richard and John Gathergood. Financial Literacy and Customer Credit Use. Centre For Finance And Credit Markets School of Economics. Working Paper 12/01.

Farah Yasmin, et al. Determinants of Economic Literacy at University Level : A Case of Pakistan. Pakistan Journal of Commerce and Social Sciences 2014, Vol.8 (3), 914924.

Juliana. (2013). Artikel : Pengaruh Literasi Ekonomi Terhadap Perilaku Konsumsi Mahasiswa Pendidikan Ekonomi FKIP UNTAN. Pontianak : UNTAN

Kanserina Dias. (2015). Artikel : Pengaruh Literasi Ekonomi Dan Gaya Hidup Terhadap Perilaku Konsumtif Mahasiswa Jurusan Pendidikan Ekonomi Undiksha 2015.

Nuraeni. (2015). Skripsi : Pengaruh Literasi Ekonomi, Kelompok Teman Sebaya, Dan Kontrol Diri Terhadap Perilaku Pembelian Impulsif Untuk Produk Fashion Pada Mahasiswa Fakultas Ekonomi Universitas Negeri Yogyakarta. Yogyakarta : UNY.

Sina, Peter Garlans. (2012). Analisis Literasi Ekonomi. Salatiga : Alumni Magister Manajemen UKSW 